\title{
Anti-inflammatory effect of bee pollen ethanol extract from Cistus sp. of Spanish on carrageenan-induced rat hind paw edema
}

\author{
Hiroe Maruyama', Takashi Sakamoto', Yoko Araki and Hideaki Hara*2
}

\begin{abstract}
Background: Bee pollen, a honeybee product, is the feed for honeybees prepared themselves by pollens collecting from plants and has been consumed as a perfect food in Europe, because it is nutritionally well balanced. In this study, we aimed to investigate the anti-inflammatory effect of bee pollen from Cistus sp. of Spanish origin by a method of carrageenan-induced paw edema in rats, and to investigate the mechanism of anti-inflammatory action and also to elucidate components involved in bee pollen extracted with ethanol.

Methods: The bee pollen bulk, its water extract and its ethanol extract were administered orally to rats. One hour later, paw edema was produced by injecting of $1 \%$ solution of carrageenan, and paw volume was measured before and after carrageenan injection up to $5 \mathrm{~h}$. The ethanol extract and water extract were measured COX-1 and COX-2 inhibitory activities using COX inhibitor screening assay kit, and were compared for the inhibition of NO production in LPSstimulated RAW 264.7 cells. The constituents of bee pollen were purified from the ethanol extract subjected to silica gel or LH-20 column chromatography. Each column chromatography fractions were further purified by repeated ODS or silica gel column chromatography.

Results: The bee pollen bulk mildly suppressed the carrageenan-induced paw edema and the water extract showed almost no inhibitory activity, but the ethanol extract showed relatively strong inhibition of paw edema. The ethanol extract inhibited the NO production and COX-2 but not COX-1 activity, but the water extract did not affect the NO production or COX activities. Flavonoids were isolated and purified from the ethanol extract of bee pollen, and identified at least five flavonoids and their glycosides.

Conclusions: It is suggested that the ethanol extract of bee pollen show a potent anti-inflammatory activity and its effect acts via the inhibition of NO production, besides the inhibitory activity of COX-2. Some flavonoids included in bee pollen may partly participate in some of the anti-inflammatory action. The bee pollen would be beneficial not only as a dietary supplement but also as a functional food.
\end{abstract}

\section{Background}

There are roughly two groups of pollen materials. One group is made by honeybees and the other is directly collected from the flower of plants. The former group is the feed for honeybees prepared by mixing honey with pollens collected from plants and called bee pollen or pollen ball. Bee pollen is collected by beekeepers with the use of a screen over hive openings designed specifically to let the bees pass while squeezing pollen from their hind legs

* Correspondence: hidehara@gifu-pu.ac.jp

2 Department of Biofunctional Evaluation, Molecular Pharmacology, Gifu Pharmaceutical University, 1-25-4 Daigaku-nishi, Gifu 501-1196, Japan Full list of author information is available at the end of the article and pollen sacs, and has its own specificity, mainly linked to the floral species or cultivars [1].

Bee pollen is rich in protein, particularly free amino acids, and also abounds with carbohydrate, lipid, vitamins and minerals [2,3]. In addition, bee pollen contains minor components, such as flavonoids and phenolic compounds $[4,5]$. Bee pollen, which is nutritionally well balanced, has been consumed as a perfect food in Europe and the U.S. for a long time.

Although there have been many studies on the functionality of pollens directly collected from plants, there have not been many reports on the functionality of bee 
pollen. There have been some reports on bee pollen but they provided extremely few data by source plant. It has been reported that bee pollen from Cistus sp. of Spanish origin prevents osteoporosis by increasing bone mass and exhibits antiallergic action [6-10]. In addition, bee pollen has been reported to show antioxidant and radical scavenging activities [11], and recently, Akkol et al. have reported that antinociceptive, anti-inflammatory, gastroprotective and antioxidant effects of pure honey and honey-bee pollen mix formulation were evaluated comparatively [12].

Concerning pollens directly collected from plants, their effect on prostatitis in men and anti-inflammatory effect in animal experiments have been confirmed though their active components for anti-inflammatory action have not been identified $[13,14]$. On the other hand, phenolic and flavonoid components of honey-bee pollen mix involved in anti-inflammatory action have been reported by Akkol et al. [12].

In this study, we aimed to investigate the anti-inflammatory effect of bee pollen from Cistus sp. of Spanish origin by a method of carrageenan-induced paw edema in rats, and to investigate the mechanism of anti-inflammatory action and also to elucidate components involved in bee pollen extracted with ethanol.

\section{Methods}

\section{Materials}

Bee Pollen from Cistus sp. of Spanish origin and Bee Pollen from Brassica sp. of China origin were obtained from Api Co., Ltd.

The following drugs and chemicals were purchased and used: $\lambda$-carrageenan, indomethacin (Wako Pure Chemical Industries, Ltd., Osaka, Japan), lipopolysaccaride (LPS), Griess reagent, DMEM and other cell culture reagents including FBS (Sigma Chemical Co., St. Louis, MO, U.S.A.).

\section{Particle size distribution}

Particle size distribution of bee pollen from Cistus sp. and Brassica sp. were measured by Coulter counter multisizer TM3. (Beckman Coulter, Miami, FL, U.S.A.) [15,16]. A Coulter counter with $100 \mu \mathrm{m}$ aperture (particle size; 2-60 $\mu \mathrm{m}$, counting particles; 50000) was used for particle analysis. Before the analysis, each sample was diluted with electrolyte solution (ISOTON II) to the appropriate concentration of particles and sonicated for $5 \mathrm{~min}$. The obtained distribution was a volume distribution.

\section{Bee pollen extracts}

Each $200 \mathrm{~g}$ of bee pollen (BP) from Cistus sp. of Spanish origin was extracted with water (Water BP) or 95\% ethanol (EtOH BP), and stirred for $4 \mathrm{~h}$ at $60^{\circ} \mathrm{C}$ or stirred for 16 $\mathrm{h}$ at room temperature, respectively. The filtrate was taken to dryness and powdered. The yields were $40.9 \%$ (Water BP, $81.8 \mathrm{~g}$ ) and 17.1\% (EtOH BP, $34.2 \mathrm{~g}$ ).

\section{Animals}

Male Wistar rats of 6 weeks old were obtained from SLC Japan, Inc. (Shizuoka, Japan). Animals were housed in steel cages in a room kept at $23^{\circ} \mathrm{C}$ with a 12 -h light-dark cycle (lights on 8:00-20:00), and fed a laboratory diet (CEII, CLEA Japan, Inc., Tokyo, Japan). Water was freely available. The animal experimental protocol was approved prior to its execution by our in-house committee in accordance with the National Institute of Health Guideline for the Care and Use of Laboratory Animals, the Japanese Government Animal Protection and Management Law Number 105 and the Japanese Government Notification on Feeding and Safekeeping of Animals Number 6.

\section{Carrageenan-induced rat hind paw edema}

Male Wistar rats were fasted for $16 \mathrm{~h}$ and used in groups of 4, each containing 7 individuals. Bee Pollen $(300 \mathrm{mg} /$ $\mathrm{kg}$ ), Water BP (300 mg/kg), EtOH BP (100 and $300 \mathrm{mg} /$ $\mathrm{kg}$ ) and indomethacin $(30 \mathrm{mg} / \mathrm{kg}$ ) were suspended in a $5 \%$ solution of gum Arabic (vehicle) and were administered orally. One hour later, paw edema was produced by injecting $100 \mu \mathrm{l}$ of $1 \%$ solution of carrageenan in saline into the left hind paw. Paw volume was measured before and after carrageenan injection up to $5 \mathrm{~h}$, using a water displacement plethysmometry (plethysmometer MK-550, Muromachi Kikai Co., Tokyo, Japan). The swelling ratio (\% swelling) was expressed as the percentage of the increase in paw volume before carrageenan injection [17].

\section{Cox inhibitory activity}

EtOH BP and Water BP were measured COX inhibitory activities of COX inhibitor screening assay kit (Cayman Chemical Company, Ann Arbor, MI, U.S.A) [18-20]. The COX inhibitor screening assay directly measures $\mathrm{PGF}_{2 \alpha}$ produced by $\mathrm{SnCl}_{2}$ reduction of $\mathrm{COX}$-derived $\mathrm{PGH}_{2}$ produced in the COX reaction. All procedures were performed as indicated in the assay kit instructions. Briefly, the reaction buffer (Tris- $\mathrm{HCl}$ buffer, $\mathrm{pH} 8.0$, containing 5 $\mathrm{mM}$ EDTA and $2 \mathrm{mM}$ phenol) and heme were placed in test tubes [18]. The sample and COX-1 or COX-2 were added to the test tubes and pre-incubated for $10 \mathrm{~min}$ at $37^{\circ} \mathrm{C}$. After the substrate arachidonic acid was added, the test tubes were incubated for $2 \mathrm{~min}$ at $37^{\circ} \mathrm{C}$. The concentration of $\mathrm{PGF}_{2 \alpha}$ was measured using the enzyme immunoassay (EIA) of the same kit. EtOH BP and Water BP samples were added to the test tubes at final concentrations of $150,50,16.7$ and $5.6 \mu \mathrm{g} / \mathrm{ml}$ within the range of three time dosage ratio. All samples were added as dimethyl sulfoxide (DMSO) solutions to assay solutions, and all determinations were performed in triplicate $(\mathrm{N}=3)$. 
Values for $50 \%$ inhibitory concentration $\left(\mathrm{IC}_{50}\right)$ were obtained by linear regression analysis.

RAW 264.7 cell culture and measurement of NO production RAW 264.7 cells obtained from the American Type Culture Collection were cultured with DMEM supplemented with $10 \% \mathrm{FBS}$ and $1 \%$ antibiotics under $5 \% \mathrm{CO}_{2}$ at $37^{\circ} \mathrm{C}$ and activated with LPS according to the previously described procedures [21,22]. In brief, the cells were plated in 96-well plates $\left(2 \times 10^{5}\right.$ cells/well). After preincubation for $2 \mathrm{~h}$, the test samples including EtOH BP or Water BP and LPS $(1 \mu \mathrm{g} / \mathrm{ml})$ were added and the cells were incubated for $24 \mathrm{~h}$. Test samples were dissolved in DMSO on the day of the experiment and diluted with serum-free DMEM into appropriate concentrations. Final concentration of DMSO was adjusted to $0.1 \%(\mathrm{v} / \mathrm{v})$. Control groups also received the same amount of DMSO. Cell viability was assessed with MTT assay. For a determination of NO concentration, the amount of nitrite in the cell culture supernatant measured by using Griess reagents. The cell culture medium was mixed with Griess reagent and incubated for $10 \mathrm{~min}$ at room temperature. The optical density was measured with a microplate reader ( $\mu$ Quant, BIO-TEK instruments, Inc., VT, U.S.A.). at 550 $\mathrm{nm}$. Nitrite was quantified by using sodium nitrate as a standard. Values for $50 \%$ inhibitory concentration $\left(\mathrm{IC}_{50}\right)$ were obtained by linear regression analysis.

Fractionation of bee pollen and Identification of flavonoids Bee pollen from Cistus sp. of Spanish origin was successively extracted with water two times, and then the residue was extracted two times with hexane and two times with ethanol, subsequently. These procedures were performed at room temperature. Evaporation of the solvents in vacuo gave water, hexane and ethanol extracts.

The process of isolation is shown in Figure 1. Ethanol extract ( $31 \mathrm{~g}$, Figure 1 left side) was further purified using the silica gel column chromatography $\mathrm{CHCl}_{3}-\mathrm{MeOH}$ system (gradually replaced with $\mathrm{MeOH} 20-50 \%$ ) [23,24]. Fractions were collected and their composition monitored by TLC (solvents: $\mathrm{CHCl}_{3}-\mathrm{MeOH}=7: 3$ ) and those with similar TLC profiles were combined into 27 major fractions denoted as Fr. 1 to Fr. 27. Each fraction was collected and dried. Fraction 11 and 16 was further purified by ODS column chromatography methanol-1\% acetic acid system, finally yielding purified compound A (4.9 $\mathrm{mg}$, kaempferol-3-glucoside) and B (20 mg, quercetin-7rhamnoside). And, ethanol extract ( $2 \mathrm{~g}$, Figure 1 right side) was applied to Sephadex ${ }^{\text {tax }}$ LH-20 (Amersham Biosciences, Piscataway, NJ, U.S.A.) column chromatography $(\varphi 25 \mathrm{~mm} \times 270 \mathrm{~mm})$ eluted with methanol. Fractions (each $5 \mathrm{ml}$ ) were collected and their composition monitored by TLC (solvents: $\mathrm{CHCl}_{3}-\mathrm{MeOH}=7: 3$ ) and those with similar TLC profiles were combined into 4 major fractions denoted as Fr. 1 to Fr. 4. Each fraction was collected and dried. Fraction 4 was further purified by silica gel column chromatography $\mathrm{CHCl}_{3}-\mathrm{MeOH}$ system, and finally yielding purified compound $\mathrm{C}$ (isorhamnetin), compound D (kaempferol), and compound $\mathrm{E}$ (quercetin). Flavonoids were identified by ${ }^{1} \mathrm{H}-\mathrm{NMR},{ }^{13} \mathrm{C}-\mathrm{NMR}$ and 2D-NMR (Varian, MERCURY plus $300 \mathrm{MHz}$; Varian Technologies Japan Ltd., Osaka, Japan) spectroscopic methods. The chemical shift values are reported in ppm $(\delta)$, and the coupling constants $(\mathrm{J})$ are reported in $\mathrm{Hz}$. Electro spray ionization mass spectra (ESI-MS) were obtained on a LCQ mass spectrometer (Thermo Fisher Scientific) and wherever possible by chromatographic TLC and high-performance liquid chromatography (HPLC) comparisons with authentic markers. An HPLC system equipped with a model 2695 or 996-Photodiodearray detector was used (Waters, Osaka, Japan). Chromatography was performed at $40^{\circ} \mathrm{C}$ using a CAPCELLPAK ACR column (Shiseido, Tokyo, Japan). Elution was performed in stepwise gradient mode. A: $\mathrm{H}_{2} \mathrm{O}$ containing $1 \%$ acetic acid. $\mathrm{B}: \mathrm{CH}_{3} \mathrm{CN}$ containing $1 \%$ acetic acid [B concentration $20 \mathrm{~T} 80 \%$ (0T60 $\mathrm{min}, 80 \%$ hold (60-70 $\mathrm{min}$ )] at a flow rate of $1.0 \mathrm{ml} / \mathrm{min}$.

\section{Data Analysis}

In animal experiments, the results are expressed as means and standard deviations (S.D.). The significance of the differences was analyzed by Dunnett's multiple-range test.

\section{Results}

\section{Particle size distribution}

Figure 2 shows the particle size distributions of bee pollen from Cistus sp. and Brassica sp. The two kinds of bee pollens were clearly differed in distribution pattern. Bee pollen from Cistus sp. had a main peak in a range of 40-50 $\mu \mathrm{m}$. In contrast, the one from Brassica sp. had a main peak near $28 \mu \mathrm{m}$ and a small peak near $20 \mu \mathrm{m}$. Therefore, bee pollen from Cistus sp. showed more homogenous in flower composition.

\section{Anti-inflammatory effects of bee pollen on carrageenan- induced edema in rat hind paws}

After $100 \mu \mathrm{l}$ of $1 \%$ carrageenan was injected into the hind paw, the paw edema in the control rats increased along with the time course and the peak edema was showed at 4 $\mathrm{h}$ (Figure 3A and Figure 4A). Mean \% swelling of control group rats was 70.4 and $70.7 \%$ at $4 \mathrm{~h}$ (Figure $3 \mathrm{~B}$ and Figure 4B). Bee Pollen from Cistus sp. at the dose of $300 \mathrm{mg} /$ $\mathrm{kg}$ slightly, but significantly decreased the edema and 30 $\mathrm{mg} / \mathrm{kg}$ dose of indomethacin significantly decreased the edema, 59.0 and $30.5 \%$ of swelling, respectively. Water BP at the dose of $300 \mathrm{~m} / \mathrm{kg}$ almost did not affect the paw edema (Figure 3A and 3B). 


\section{Ethanol ext. Ethanol ext.}

silica gel column chromatography

which was eluted gradually

with $\mathrm{CHCl}_{3}$ and Methanol. $8: 2 \rightarrow 6: 4 \rightarrow 5: 5$

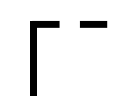

Fr.1
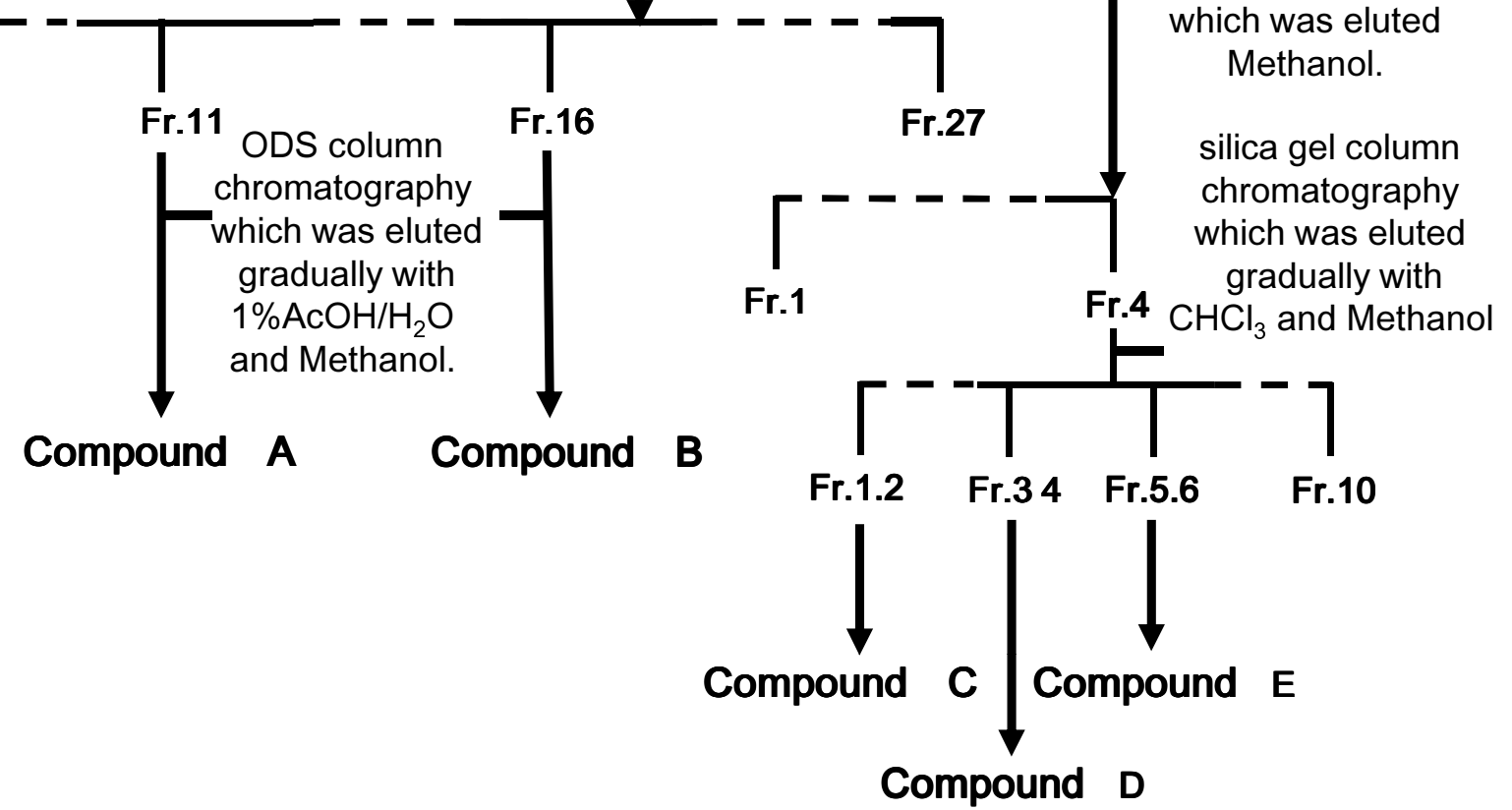

Figure 1 Flowchart of the isolation process for the ethanol extract of bee pollen. Ethanol extract of bee pollen was subjected to silica gel column chromatography eluted with $\mathrm{CHCl}_{3}$ and methanol or Sephadex ${ }^{\mathrm{TM}} \mathrm{LH}-20$ column chromatography eluted with methanol. Each column chromatography fractions were further purified by repeated ODS or silica gel column chromatography, finally yielding purified 5 compounds.

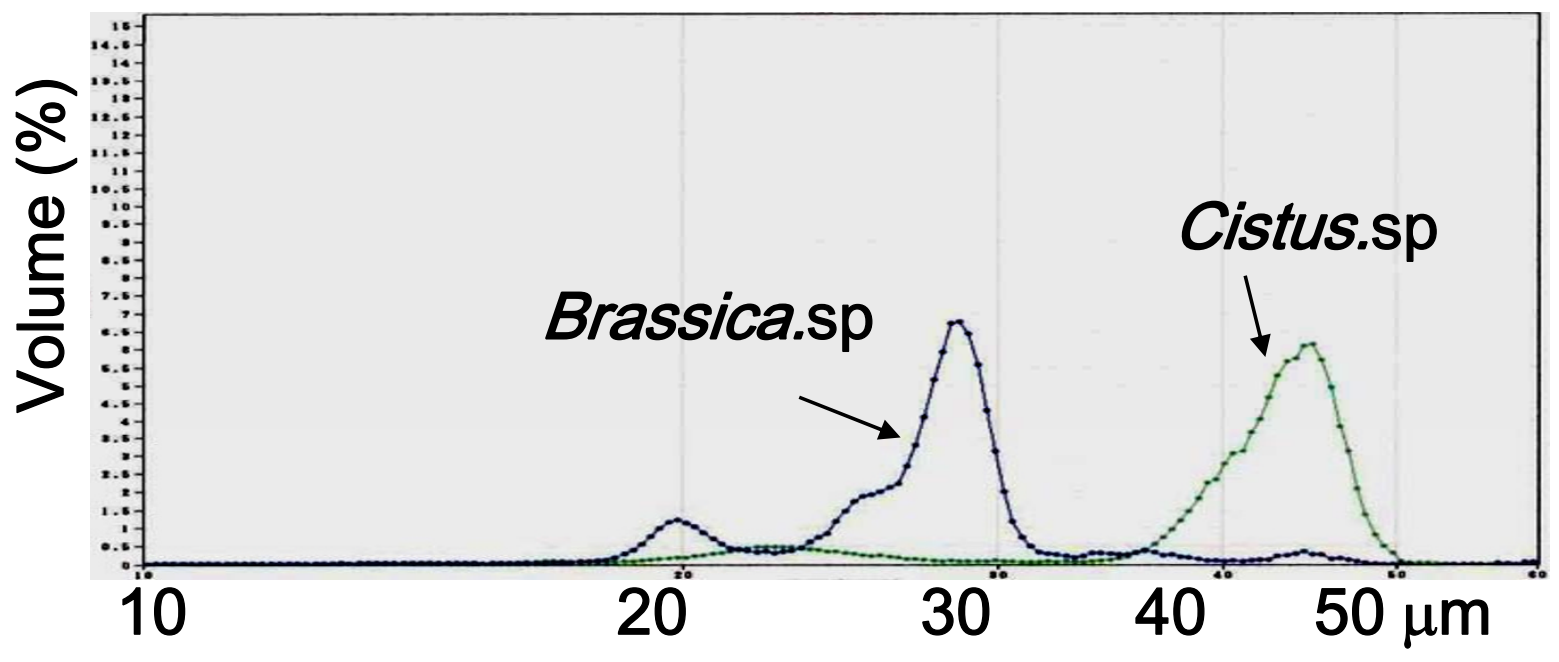

Figure 2 Particle size distribution of bee pollen from Cistus sp. and Brassica sp. determined by Coulter counter. A Coulter counter with 100 $\mu \mathrm{m}$ aperture (particle size; 2-60 $\mu \mathrm{m}$, particle counting; 50000) was used for particle analysis. Before the analysis, each sample was diluted with electrolyte solution to the appropriate concentration of particles and sonicated for $5 \mathrm{~min}$. 


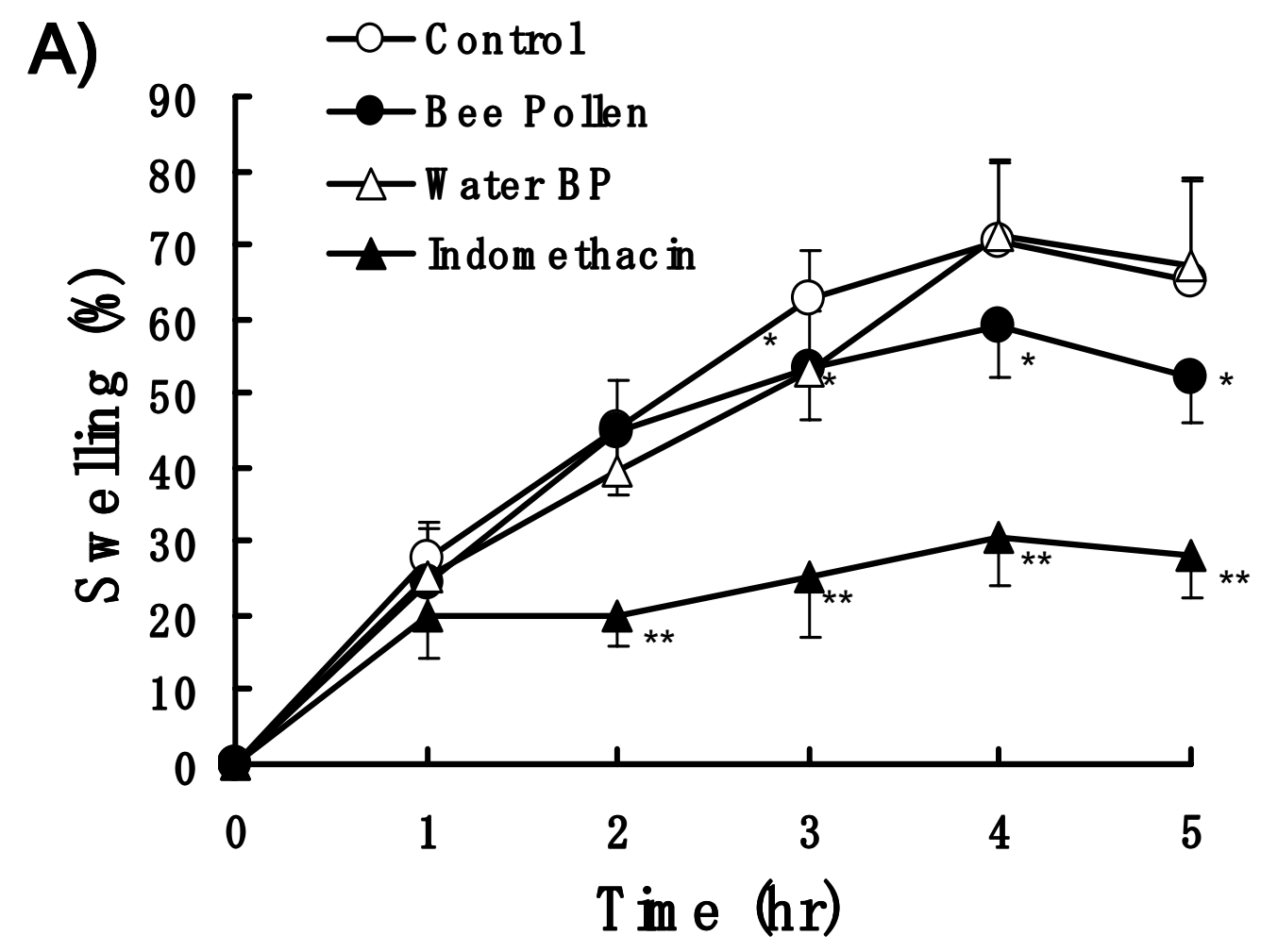

B)

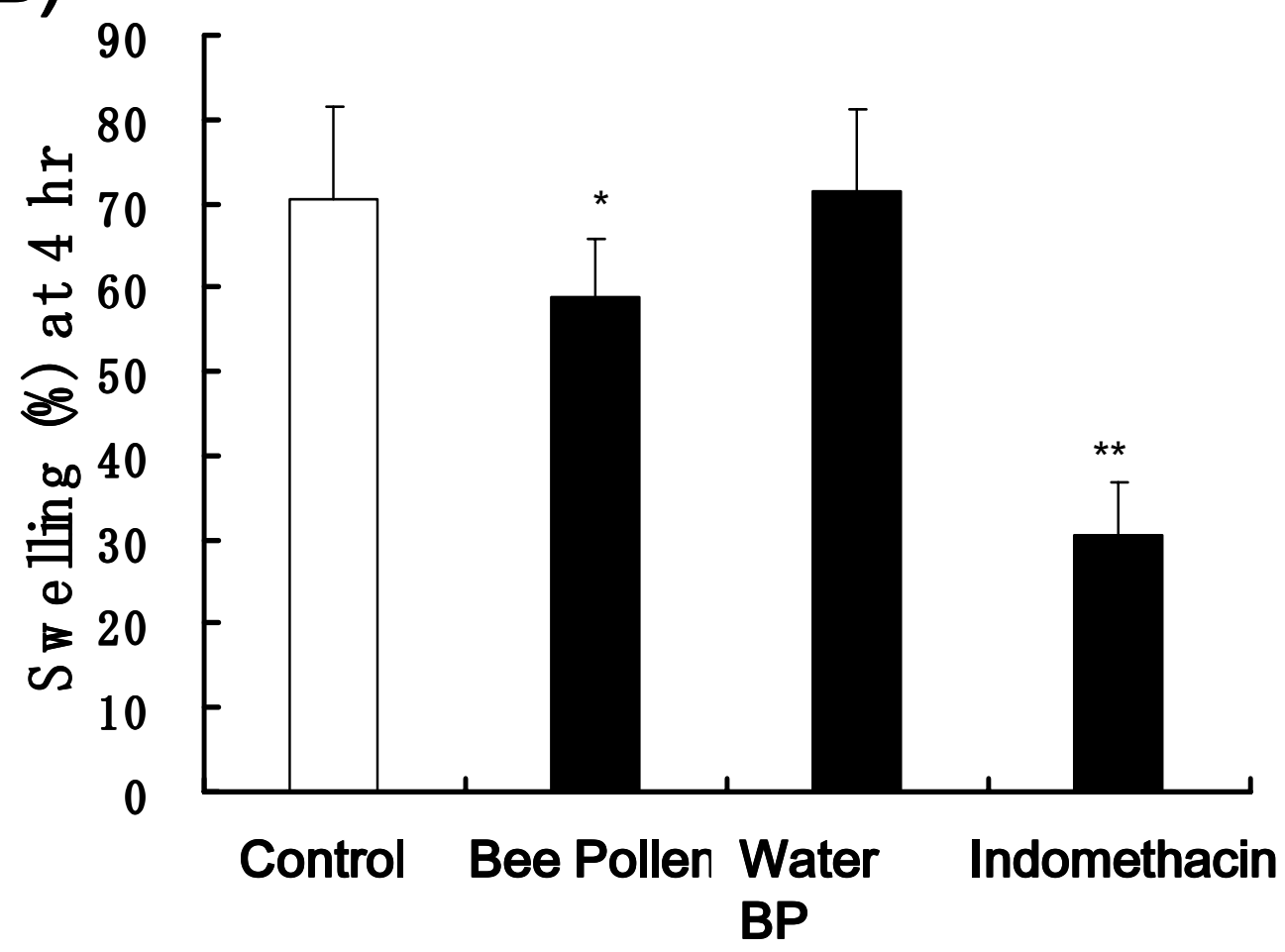

Figure 3 Effects of bee pollen and indomethacin on carrageenan-induced paw edema in rats. Bee pollen (300 mg/kg), Water BP (300 mg/kg) and indomethacin (30 mg/kg) were administered orally 60 min before carrageenan injection. (A) Time course of paw edema. (B) The swelling \% measured $4 \mathrm{~h}$ after carrageenan injection. Values represent the mean $\pm \mathrm{SD}, n=7 .{ }^{*} P<0.05$, ${ }^{* *} P<0.01 \mathrm{vs}$. control (Dunnett's multiple-range test). 


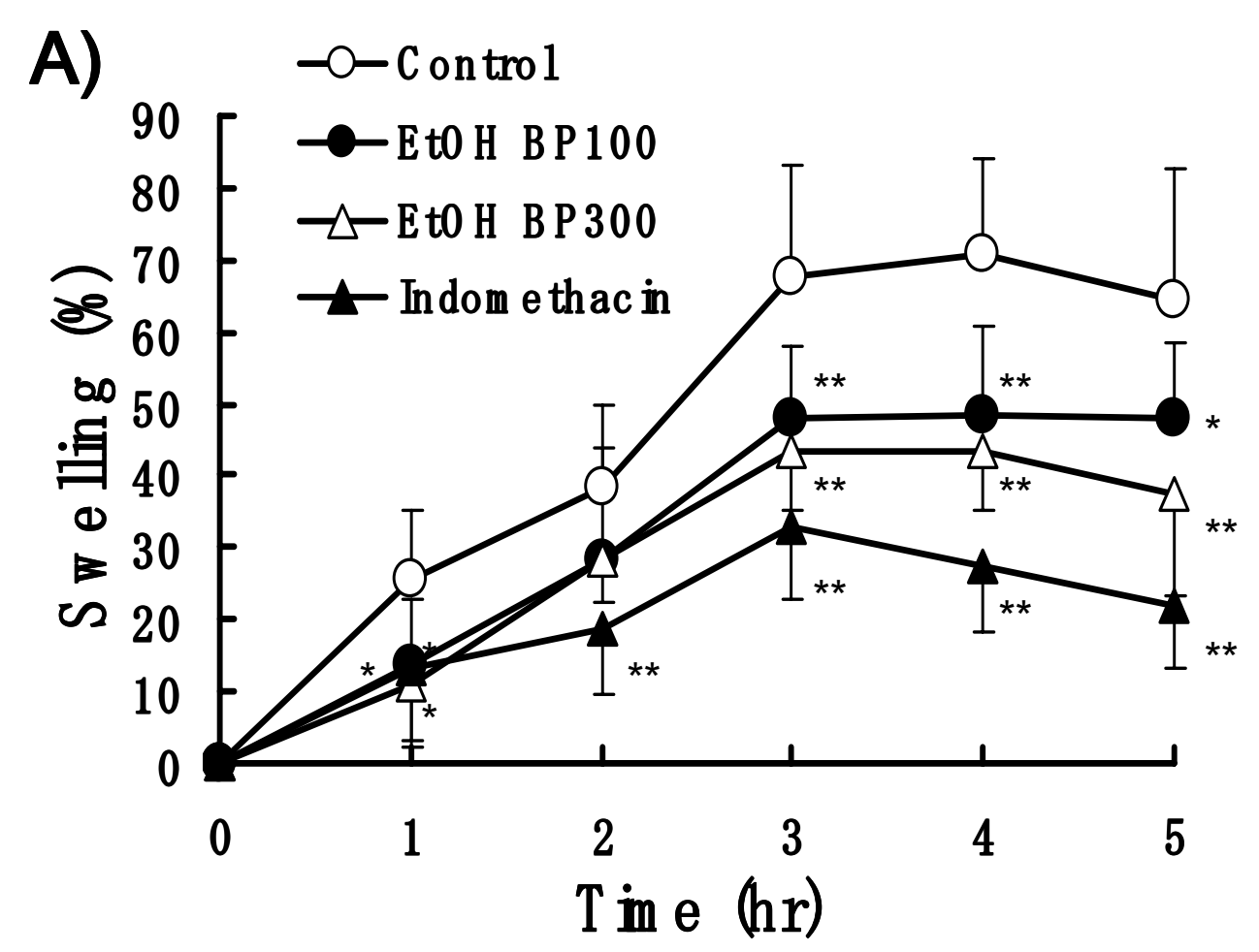

B)

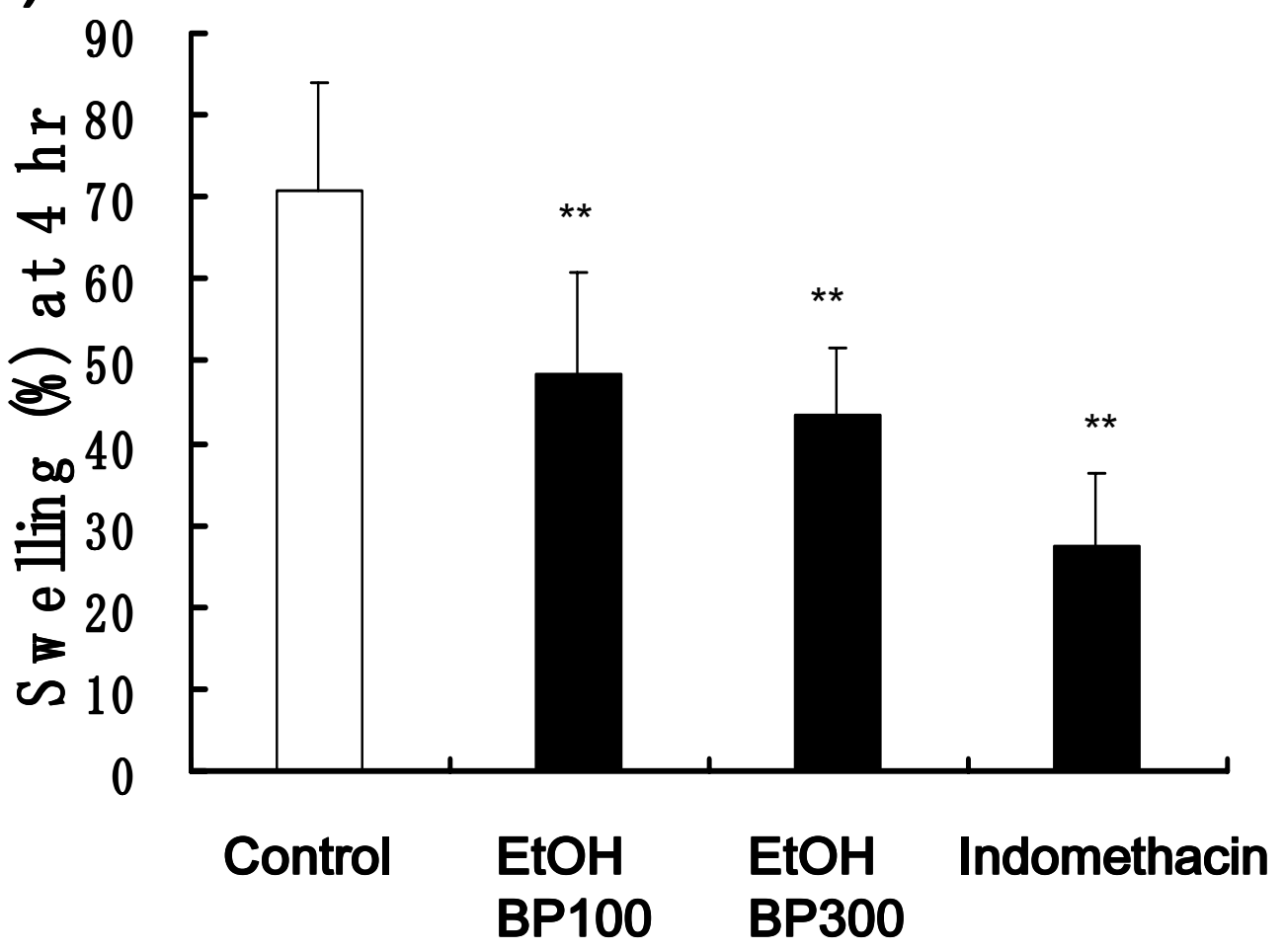

Figure 4 Effects of bee pollen and indomethacin on carrageenan-induced paw edema in rats. EtOH BP (100 and $300 \mathrm{mg} / \mathrm{kg}$ ) and indomethacin (30 mg/kg) were administered orally 60 min before carrageenan injection. (A) Time course of paw edema. (B) The swelling \% measured $4 \mathrm{~h}$ after carrageenan injection. Values represent the mean $\pm \mathrm{SD}, n=7 .{ }^{*} P<0.05,{ }^{* *} P<0.01 \mathrm{vs}$. control (Dunnett's multiple-range test). 
On the other hand, EtOH BP (100 and $300 \mathrm{mg} / \mathrm{kg}$ ) showed relatively strong and significantly inhibition of carrageenan-induced edema. Mean \% swelling of 100 and $300 \mathrm{mg} / \mathrm{kg}$ of EtOH BP and indomethacin $(30 \mathrm{mg} / \mathrm{kg})$ was $48.4,43.5$ and $27.3 \%$, respectively (Figure $4 \mathrm{~A}$ and $4 \mathrm{~B}$ ).

\section{Inhibition of the COX-1 and COX-2 activities}

EtOH BP and Water BP were measured COX inhibitory activities using COX inhibitor screening assay kit. The inhibitory effects on COX-1 and COX-2 of EtOH BP showed concentration-dependently (Figure 5). As regards the COX-2 experiment, all EtOH BP groups showed significant decrease as compared with the control value (5.6 $\mu \mathrm{g} / \mathrm{ml} ; \mathrm{p}<0.05,16.7$ and $50 \mu \mathrm{g} / \mathrm{ml} ; \mathrm{p}<0.01)$. The $\mathrm{IC}_{50}$ values for COX-1 and COX-2 were $>150 \mu \mathrm{g} / \mathrm{ml}$ and $10.3 \mu \mathrm{g} /$ $\mathrm{ml}$, respectively. However, the inhibition of COX-2 activity of Water BP was lower than that of EtOH BP, and no differences in the COX-1 and COX-2 experiment were observed between Water BP group and the control group. The $\mathrm{IC}_{50}$ values for both COX-1 and COX- 2 were $>150$ $\mu \mathrm{g} / \mathrm{ml}$.

\section{Effect of bee pollen extracts on NO production}

RAW 264.7 cells were incubated for $24 \mathrm{~h}$ in medium containing three different concentrations of the bee pollen extract of each EtOH BP and Water BP and LPS $(1 \mu \mathrm{g} /$ $\mathrm{ml})$. EtOH BP inhibited concentration-dependently the LPS-induced production of nitrite (Figure 6) and its $\mathrm{IC}_{50}$ value was $23.2 \mu \mathrm{g} / \mathrm{ml}$. However, Water BP did not inhibit the NO production. The cytotoxic effect of EtOH BP and Water BP were not observed under same experimental condition (data not shown).

\section{Isolation and identification of flavonoids}

The results of the present study indicated that the antiinflammatory effect of ethanol extract of bee pollen from Cistus sp. of Spanish origin was stronger than those of bulk and water extract of bee pollen. Therefore, we isolated the flavonoid components in the ethanol extract of bee pollen. The purity of these flavonoids, yielding compound A (180 mg), compound B (5 mg), compound C (3 $\mathrm{mg})$, compound $\mathrm{D}(5 \mathrm{mg})$ and compound $\mathrm{E}(10 \mathrm{mg})$ was confirmed to be $90 \%$ or more by HPLC analysis.

The NMR data of compounds A to $\mathrm{E}$ are as follows:

\section{Compound A: Kaempferol-3-glucoside}

${ }^{1} \mathrm{H}-\mathrm{NMR}$ (DMSO- $\mathrm{d}_{6}$ ) $\delta: 3.1-3.8$ (m, -glucose), $5.2(1 \mathrm{H}, \mathrm{d}, \mathrm{J}$

$=7 \mathrm{~Hz}$, glucose), $5.7(1 \mathrm{H}, \mathrm{d}, \mathrm{J}=2.5 \mathrm{~Hz}, \mathrm{H}-6), 5.8(1 \mathrm{H}, \mathrm{d}, \mathrm{J}$

$=2.5 \mathrm{~Hz}, \mathrm{H}-8), 6.9\left(2 \mathrm{H}, \mathrm{d}, \mathrm{J}=9 \mathrm{~Hz}, \mathrm{H}-3^{\prime}, 5^{\prime}\right), 8.06(2 \mathrm{H}, \mathrm{d}, \mathrm{J}$

$\left.=9 \mathrm{~Hz}, \mathrm{H}-2^{\prime}, 6^{\prime}\right)$.

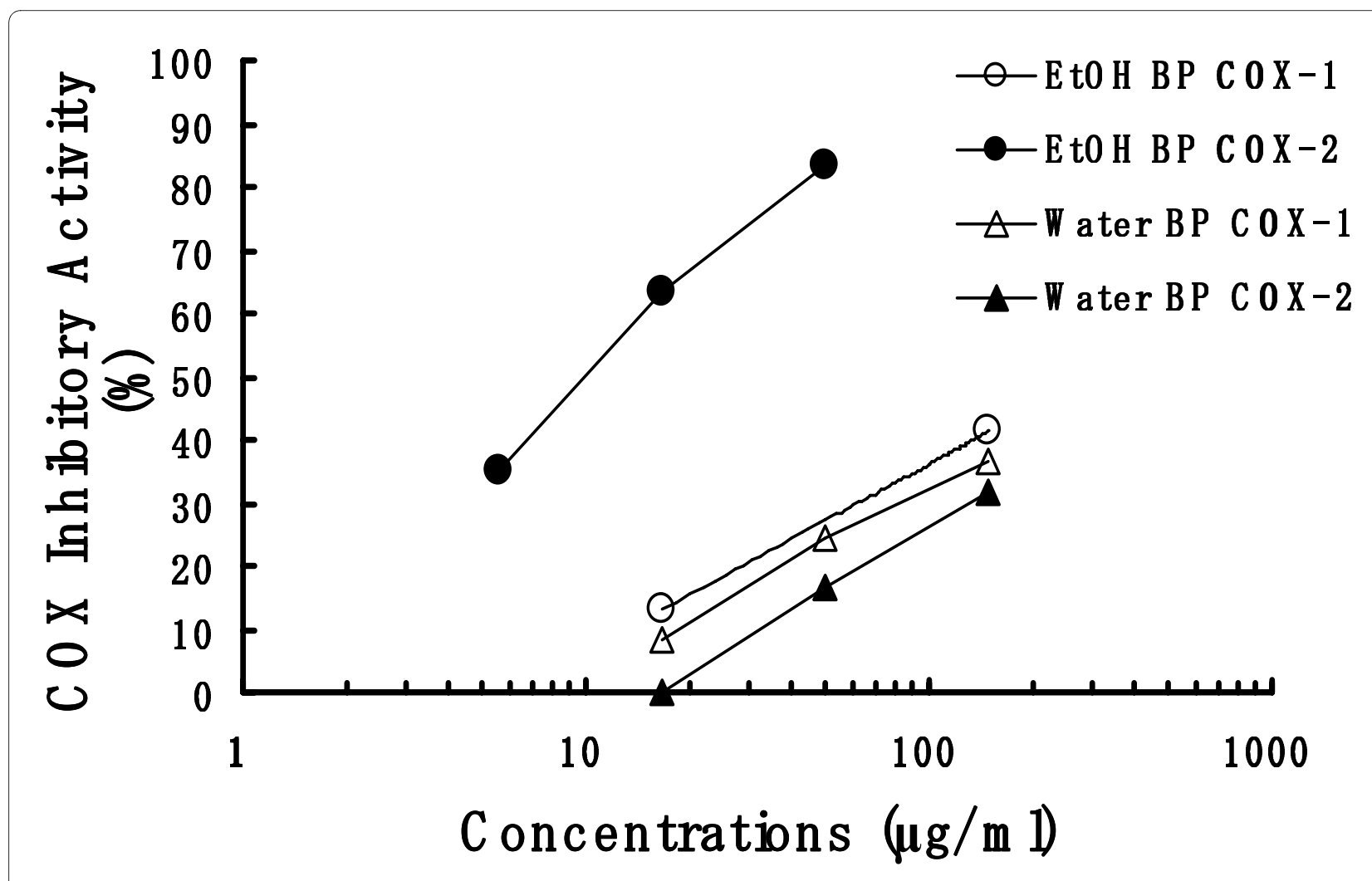

Figure 5 The inhibitory effect of bee pollen on COX-1 and COX-2. Each extracts of bee pollen (EtOH BP and Water BP) were measured COX inhibitory activities of COX inhibitor screening assay kit. The COX inhibitory activity (\%) was represented as inhibition \% of control (solvent-treated samples). 


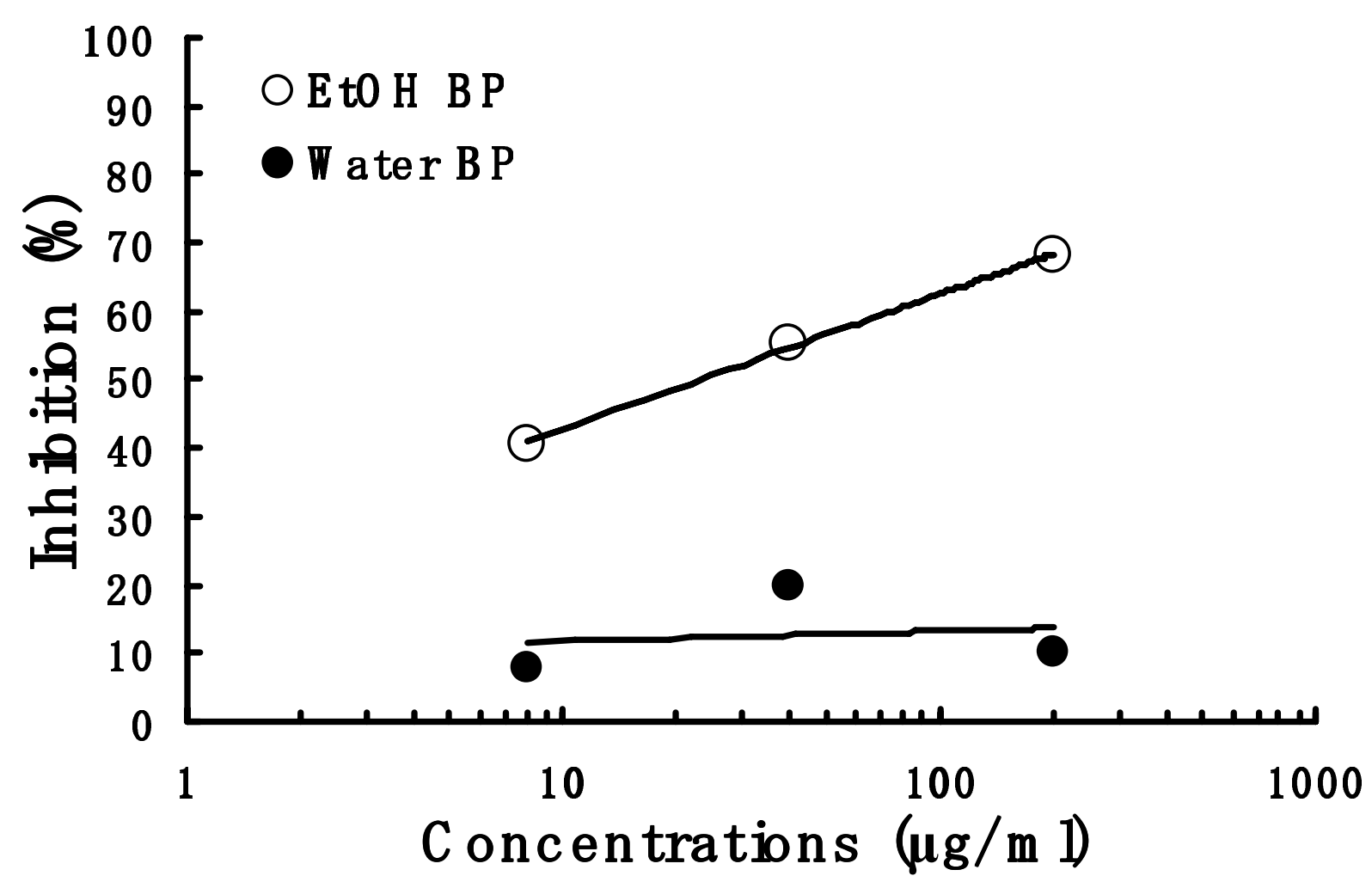

Figure 6 Effect of bee pollen on NO production in LPS-stimulated RAW 264.7 cells. The production of NO was detected and analyzed using Griess reagent. RAW 264.7 cells were incubated for $24 \mathrm{~h}$ at $37^{\circ} \mathrm{C}$ in medium containing three different concentrations of the bee pollen extract of each EtOH BP and Water BP and LPS (1 $\mathrm{\mu g} / \mathrm{ml})$. Results were expressed as an inhibition \% of control (solvent-treated samples).

\section{Compound B: Quercetin-7-rhamnoside}

${ }^{1} \mathrm{H}-\mathrm{NMR}\left(\mathrm{DMSO}_{6}\right) \delta: 1.2\left(3 \mathrm{H}, \mathrm{m}, \mathrm{J}=6 \mathrm{~Hz}, \mathrm{CH}_{3}\right), 5.5$

$(1 \mathrm{H}, \mathrm{d}, \mathrm{J}=2.5 \mathrm{~Hz}$, rhamnose $), 6.2(1 \mathrm{H}, \mathrm{d}, \mathrm{J}=2.5 \mathrm{~Hz}, \mathrm{H}-6)$, $6.2(1 \mathrm{H}, \mathrm{d}, \mathrm{J}=2.5 \mathrm{~Hz}, \mathrm{H}-6), 6.4(1 \mathrm{H}, \mathrm{d}, \mathrm{J}=2.5 \mathrm{~Hz}, \mathrm{H}-8)$, $6.8\left(1 \mathrm{H}, \mathrm{d}, \mathrm{J}=8.5 \mathrm{~Hz}, \mathrm{H}-5^{\prime}\right), 7.3\left(1 \mathrm{H}, \mathrm{dd}, \mathrm{H}-6^{\prime}\right), 7.4(1 \mathrm{H}, \mathrm{d}, \mathrm{J}$ $\left.=8.5 \mathrm{~Hz}, \mathrm{H}-2^{\prime}\right)$.

\section{Compound C: Isorhamnetin}

${ }^{1} \mathrm{H}-\mathrm{NMR}\left(\mathrm{DMSO}_{\mathrm{d}}\right)$ $\delta: 3.84(3 \mathrm{H}, \mathrm{s},-\mathrm{OMe}), 6.19(1 \mathrm{H} \mathrm{d}$, H-6), 6.47 (1H, d, H-8), 6.99 (1H, d, J = 8.5 Hz, H-5'), 7.68 $\left(1 \mathrm{H}, \mathrm{dd}, \mathrm{J}=8.5,2.1 \mathrm{~Hz}, \mathrm{H}-2{ }^{\prime}, 6^{\prime}\right), 7.75(2 \mathrm{H}, \mathrm{dd}, \mathrm{J}=2.1 \mathrm{~Hz}$, H-2'), 12.47 (1H, s, -OH).

\section{Compound D: Kaempferol}

${ }^{1} \mathrm{H}-\mathrm{NMR}\left(\mathrm{DMSO}_{\mathrm{d}}\right.$ ) $\delta: 6.18$ (1H, brs, H-6), 6.39 (1H, brs, $\mathrm{H}-8), 6.92\left(2 \mathrm{H}, \mathrm{d}, \mathrm{J}=8.5 \mathrm{~Hz}, \mathrm{H}-3^{\prime}, 5^{\prime}\right), 8.08(2 \mathrm{H}, \mathrm{d}, \mathrm{J}=8.9$ $\mathrm{Hz}, \mathrm{H}-2$ ',6'), 12.49 (1H, s, $-\mathrm{OH})$.

\section{Compound E: Quercetin}

${ }^{1} \mathrm{H}-\mathrm{NMR}\left(\mathrm{DMSO}-\mathrm{d}_{6}\right) \delta: 6.18(1 \mathrm{H}, \mathrm{d}, \mathrm{J}=2.5 \mathrm{~Hz}, \mathrm{H}-8), 6.40$ $(1 \mathrm{H}, \mathrm{d}, \mathrm{J}=2.5 \mathrm{~Hz}, \mathrm{H}-6), 6.86\left(1 \mathrm{H}, \mathrm{d}, \mathrm{J}=8.5 \mathrm{~Hz}, \mathrm{H}-5^{\prime}\right), 7.52$ $\left(1 \mathrm{H}, \mathrm{q}, \mathrm{J}=8.5 \mathrm{~Hz}, \mathrm{H}-6^{\prime}\right), 7.67\left(1 \mathrm{H}, \mathrm{d}, \mathrm{J}=8.5 \mathrm{~Hz}, \mathrm{H}-2^{\prime}\right)$.

These compounds were identified by HPLC and NMR, which showed that the spectra were consistent with those reported previously [25-27]. The structures of these five compounds are shown in Figure 7.

\section{Discussion}

Bee pollen contains sugars derived from honeybees and lipid complex from pollens. Because bee pollen is usually dried completely, pollen particles are sticking to one another. We added two kinds of bee pollens, one from a Cistus sp. of Spanish origin and the other from a Brassica sp. of China origin, to an electrolytic solution for dispersion and measured particle size distribution with a Coulter counter. The two kinds of bee pollens were clearly differed in distribution pattern, and the one from Cistus sp. showed more homogenous in flower composition. Therefore, the bee pollen from the Cistus sp. of Spanish origin was used in this study, because it was more homogenous in flower (pollen composition) and most frequently consumed as food in Japan.

We investigated the anti-inflammatory effect of bee pollen bulk, its water extract and its ethanol extract by a method of carrageenan-induced paw edema in rats. The bee pollen bulk mildly suppressed paw edema and the 
<smiles>C[C@@H]1[C@H]2[C@H](O[C@@H]2Oc2cc(O)c3c(=O)c(O)c(-c4ccc(O)c(O)c4)oc3c2)C(O)[C@@H]1O</smiles>

Compound A Quercetin-7-Rhamnoside

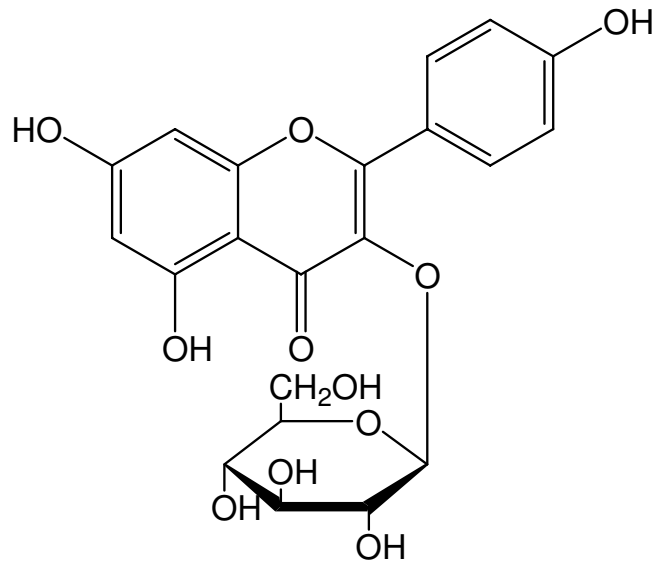

Compound B Kaempferol-3-Glucoside<smiles>COc1cc(-c2oc3cc(O)cc(O)c3c(=O)c2O)ccc1O</smiles>

Compound C Isorhamnetin<smiles>O=c1c(O)c(-c2ccc(O)cc2)oc2cc(O)cc(O)c12</smiles>

Compound D Kaempferol<smiles>O=c1c(O)c(-c2ccc(O)c(O)c2)oc2cc(O)cc(O)c12</smiles>

Compound E

\section{Quercetin}

Figure 7 Chemical structures of 5 compounds from the ethanol extract of bee pollen. Compound A: Quercetin-7-Rhamnoside; Compound B: Kaempferol-3-Glucoside; Compound C: Isorhamnetin; Compound D: Kaempferol; Compound E: Quercetin 
water extract showed almost no inhibitory activity (Figure 3), but the ethanol extract showed relatively strong inhibition of carrageenan-induced paw edema (Figure 4). These results suggest that ethanol extract of bee pollen show a potent anti-inflammatory activity.

The anti-inflammatory drugs, such as aspirin and indomethacin, have been found to inhibit prostaglandin production to cause anti-inflammatory action in carrageenan-induced paw edema [28,29]. Recently, it has also been reported that NO produced by i-NOS is involved in the inflammatory response on paw edema $[17,30]$. Therefore, the ethanol extract and water extract from the bee pollen were compared for the inhibition of NO production in RAW 264.7 cells and the inhibition of COX activity in vitro.

The water extract and ethanol extract little inhibited COX-1, but the ethanol extract inhibited COX-2 relatively strongly (Figure 5). The production of prostaglandins such as $\mathrm{PGE}_{2}$ and/or $\mathrm{PGI}_{2}$ is facilitated through COX-2 activity in inflammatory response [29]. These data indicate that the mechanism of anti-inflammatory action of the ethanol extract of bee pollen involves the inhibitory activity of COX-2.

In the experiment of NO production in RAW 264.7 cells, the water extract of bee pollen showed no suppression of NO production, but the ethanol extract inhibited NO production concentration-dependently (Figure 6). From the results, it is suggested that the anti-inflammatory effect of the ethanol extract on carrageenan-induced paw edema acts via the inhibition of NO production, besides the inhibitory activity of COX- 2 .

Flavonoids were isolated and purified from the ethanol extract fraction of the bee pollen from a Cistus sp. to identify at least five flavonoids and flavonoid glycosides: quercetin-7-rhamnoside, kaempferol-3-glucoside, isorhamnetin, kaempferol and quercetin. The Spanish bee pollen has been reported to contain their aglycones [4].

Various flavonoid derivatives including quercetin have been reported to inhibit the activity of arachidonic acid metabolizing enzymes (phospholipase $\mathrm{A}_{2}$, cycloxygenase and lipoxygenase) [31]. And it have been shown that certain flavonoids express their some of anti-inflammatory actions by modulation of proinflammatory gene expression, such as COX-2, i-NOS and several pivotal cytokines [32]. Hence, some flavonoids included in bee pollen may partly participate in some of the anti-inflammatory action, however because the inhibitory activities of COX1 and COX-2 of the ethanol extract of bee pollen are relatively selective, other unknown substances may also be involved. The total phenolic contents as well as flavonoid of honey-bee pollen mix have been estimated in the in vivo activity assessment by Akkol et al. [12]. Further studies are needed to clarify the possible mechanism for flavonoids and other constituents.

\section{Conclusions}

These findings presented here indicate that the ethanol extract of bee pollen show a potent anti-inflammatory activity and its effect acts via the inhibition of NO production, besides the inhibitory activity of COX-2. Some flavonoids included in bee pollen may partly participate in some of the anti-inflammatory action. The bee pollen would be beneficial not only as a dietary supplement but also as a functional food.

\section{Competing interests}

The authors declare that they have no competing interests.

\section{Authors' contributions}

HM, TS-Collection, analysis, and interpretation of the data; YA, HH-Design of the study management; HM, TS, YA, HH-Preparation, review, or approval of the manuscript. All authors read and approved the final manuscript.

\section{Acknowledgements}

We thank Dr. Hiroshi Izuta of API Co. Ltd., for his support.

\section{Author Details}

1Nagaragawa Research Center, API Co. Ltd. 692-3 Nagarayamasaki, Gifu 502 0071, Japan and 2Department of Biofunctional Evaluation, Molecular Pharmacology, Gifu Pharmaceutical University, 1-25-4 Daigaku-nishi, Gifu 5011196, Japan

Received: 1 March 2010 Accepted: 23 June 2010

Published: 23 June 2010

\section{References}

1. Bonvehí SJ: Plant origin of honeybee-collected pollen production in Spain. An Asoc Palinol Leng Esp 1988, 4:73-78.

2. Echigo T, Yanami K: Studies on chemical composition of pollen loads. Honeybee Sci 1986, 7:97-100.

3. Campos MG, Weddy RF, Markham KR: In bee products Plenum Press: New Yorkl; 1996.

4. Bonvehí SJ, Torrentó SM, Lorente CE: Evaluation of polyphenolic and flavonoid compounds in honeybee-collected pollen produced in Spain. J Agric Food Chem 2001, 49:1848-1853.

5. Yamaguchi I, Tsuji T: The detection of bioactive components of the powder of bee pollen. Bulletin of Tokyo Kasei University 2002, 42:111-114.

6. Yamaguchi M, Hamamoto R, Uchiyama S, Ishiyama K, Hashimoto K: Preventive effects of bee pollen Cistus ladaniferus extract in bone loss in streptozotocin-diabetic rats in vivo. J Heaith Sci 2007, 53:190-195.

7. Yamaguchi M, Uchiyama S, Nakagawa T: Preventive effects of bee pollen Cistus ladaniferus extract on bone loss in ovariectomized rats in vivo. J Health Sci 2007, 53:571-575.

8. Yamaguchi M, Uchiyama S, Nakagawa T: Anabolic effects of bee pollen Cistus ladaniferus extract in osteoblastic MC3T3-E1 cells in vitro. $J$ Health Sci 2007, 53:625-629.

9. Medeiros KC, Figueiredo CA, Figueredo TB, Freire KR, Santos FA, AlcantaraNeves NM, Silva TM, Piuvezam MR: Anti-allergic effect of bee pollen phenolic extract and myricetin in ovalbumin-sensitized mice. J Ethnoparmacol 2008, 119:41-46.

10. Ishikawa Y, Tokura T, Ushio H, Niyonsaba F, Yamamoto Y, Tadokoro T, Ogawa H, Okumura K: Lipid-soluble components of honeybeecollected pollen exert antiallergic effect by inhibiting lgE-mediated mast cell activation in vivo. Phytother Res 2009, 23:1581-1586.

11. Ikeno K, Kakimoto K, Nakamura T, Ikeno T, Shinohara R: Antioxidative activity of honeybee pollen. Honeybee Sci 2004, 25:113-118.

12. Akkol EK, Orhan DD, Gürbüz I, Yesilada E: In vivo activity assessment of a "honey-bee pollen mix" formulation. Pharm Biol 2010, 48:253-259.

13. Ito R, Noguchi K, Yamashita S, Namikata S, Takenaga K, Yoshinaga M, Shimizu K, Ishii M, Mori N: Anti-inflammatory action of cernitin pollenextract (Cernilton). Oyo Yakuri 1984, 28:55-65.

14. Duclos AJ, Lee CT, Shoskes DA: Current treatment options in the management of chronic prostatitis. Ther Clin Risk Manag 2007, 3:507-512. 
15. Kelly JK, Rasch A, Kalisz S: A method to estimate pollen viability from pollen size variation. Am J Bot 2002, 89:1021-1023.

16. Young HJ, Dunning DW, Hasseln KW: Foraging behavior affects pollen removal and deposition in Impatients Capensis (Balsaminaceae). Am J Bot 2007, 94:1267-1271.

17. Tan-no K, Nakajima T, Shoji T, Nakagawasai O, Niijima F, Ishikawa M, Endo $Y$, Sato T, Satoh S, Tadano T: Anti-inflammatory effect of propolis through inhibition of nitric oxide production on carrageenin-induced mouse paw edema. Biol Pharm Bull 2006, 29:96-99.

18. Oku H, Ishiguro K: Cyclooxygenase-2 inhibitory 1,4-naphthoquinones from Impatiens balsamina L. Bio Pharm Bull 2002, 25:658-660.

19. Handler N, Jaeger W, Puschacher H, Leisser K, Eaker T: Synthesis of novel curcumin analogues and their evaluation as selective cyclooxygenase1 (COX-1) inhibitors. Chem Pharm Bull 2007, 55:64-71.

20. Piao C, Tachikawa E, Hu Y, Sato Y, Yang P, Yamamoto K, Shinada T, Suzuki K: In vitro pharmacological activitites of the extracts from red ant Formica aquilonia as potential therapeutic agents. J Trad Med 2009, 26:61-67.

21. Park EK, Shin YW, Lee HU, Kim SS, Lee YC, Lee BY, Kim DH: Inhibitory effect of ginsenoside $\mathrm{Rb} 1$ and compound $\mathrm{K}$ on $\mathrm{NO}$ and prostaglandin $\mathrm{E} 2$ biosyntheses of RAW264.7 cells induced by lipopolysaccharide. Biol Pharm Bull 2005, 28:652-656.

22. Oh PS, Lee SJ, Lim KT: Glycoprotein isolated from Rhus verniciflua stokes inhibits inflammation-related protein and nitric oxide production in LPS-stimulated RAW 264.7 cells. Biol Pharma Bull 2007, 30:111-116.

23. Ceska O, Styles ED: Flavonoids from ZEA MAYS pollen. Phytochemistry 1984, 23:1822-1823.

24. Sang $S$, Lapsley $K$, Jeong WS, Lachance PA, Ho CT, Rosen RT: Antioxidantive Phenolic Compounds Isolated from Almond skins (Prunus amygdalus Batsch). J Agric Food Chem 2002, 50:2459-2463.

25. Breitmair E, Voelter W: VCH Verlagsgesellschaft. Weinhein 1987.

26. Amani SA, Maitland DJ, Soliman GA: Hepatoprotective activity of Schouwia thebica webb. Bioorg Med Chem Lett 2006, 16:4624-4628.

27. Lee E, Moon BH, Park Y, Lee S, Lim Y: Effects of hydroxy and methoxy substituents on NMR data in flavonols. Bull Korean Chem Soc 2008, 29:507-510.

28. Arunachalam G, Chattopadhyay D, Chatterjee S, Mandal AB, Sur TK, Mandal SC: Evaluation of anti-inflammatory activity of Alstonia macrophylla Wall ex A. DC. Leaf extract. Phyomedicine 2002, 9:632-635.

29. Noguchi M, Kimoto A, Gierse JK, Walker MC, Zweifel BS, Nozaki K, Sasamata M: Enzymologic and pharmacologic profile of loxoprofen sodium and its metabolites. Biol Pharm Bull 2005, 28:2075-2079.

30. Rioja I, Ubeda A, Terencio MC, Guillen I, Riguera R, Quintela JM, Peinador C, Gonzalez LM, Alcaraz MJ: An anti-inflammatory ditriazine inhibiting leukocyte functions and expression of inducible nitric oxide synthase and cyclo-oxygenase-2. Eur J Pharmacol 2000, 397:207-217.

31. Kim HP, Son KH, Chang HW, Kang SS: Anti-inflammatory plant flavonoids and cellular action mechanisms. J Pharmacol Sci 2004, 96:229-245

32. Chi YS, Jong HG, Son KH, Chang HW, Kang SS, Kim HP: Effects of naturally occurring prenylated flavonoids on enzymes metabolizing arachidonic acid: cyclooxygenases and lipoxygenases. Biochem Pharmacol 2001, 62:1185-1191

\section{Pre-publication history}

The pre-publication history for this paper can be accessed here: http://www.biomedcentral.com/1472-6882/10/30/prepub

doi: 10.1186/1472-6882-10-30

Cite this article as: Maruyama et al., Anti-inflammatory effect of bee pollen ethanol extract from Cistus sp. of Spanish on carrageenan-induced rat hind paw edema BMC Complementary and Alternative Medicine 2010, 10:30

\section{Submit your next manuscript to BioMed Centra and take full advantage of:}

- Convenient online submission

- Thorough peer review

- No space constraints or color figure charges

- Immediate publication on acceptance

- Inclusion in PubMed, CAS, Scopus and Google Scholar

- Research which is freely available for redistribution

Submit your manuscript at www.biomedcentral.com/submit
C Biomed Central 